\title{
NEGÓCIO JURÍDICO PROCESSUAL NO CONTENCIOSO JUDICIAL TRIBUTÁRIO
}

\author{
Daniella Zagari Gonçalves \\ Carla Mendes Novo \\ Adolpho Augusto Lima Azevedo
}

\section{INTRODUÇÃO}

Toda mudança gera certa perplexidade diante do novo, exigindo do operador do direito que revisite conceitos e, por que não dizer, preconceitos. É sempre mais confortável estar ao lado do conhecido.

Com o advento do Novo Código de Processo Civil de 2015 (NCPC), a doutrina, a jurisprudência e os operadores do direito estão sendo desafiados a novas interpretações, à quebra de paradigmas e também à busca por soluções inovadoras, tudo para que o direito processual atinja sua finalidade, seja na esfera social, política ou jurídica. ${ }^{1}$

O legislador do NCPC priorizou o método processual-constitucional, ${ }^{2}$ explicitando e valorizando as garantias constitucionais do processo e externando

1 DINAMARCO, Cândido Rangel. A instrumentalidade do processo. 15. ed. São Paulo: Malheiros, 2013.

2 Nas palavras de José Roberto dos Santos Bedaque: "A técnica constitui fator essencial à ideia de processo. Concebido este como instrumento de que a função jurisdicional do Estado se serve para colocar fim às crises existentes no plano do direito material, necessário regular a maneira como ele opera. É fundamental que o instrumento atue segundo técnica adequada e apta a possibilitar que os fins sejam atingidos. Esta é a função e formalidades processuais, cuja razão de ser encontra explicação fundamentalmente em fatores externos ao próprio processo. Mas processo não é, e nem poderia ser, somente forma. Toda a organização e a estrutura desse mecanismo encontram sua razão de ser nos valores e princípios constitucionais por ele incorporados. A 
suas ambições, dentre outras, de prestigiar a razoável duração do processo, sua efetividade e também a cooperação entre os sujeitos do processo. O princípio da cooperação, aliás, é desdobramento da garantia constitucional do contraditório, da ampla defesa e do devido processo legal. O fato de se exigir a cooperação entre as partes não significa que devam convergir sobre o direito em discussão - o que seria um contrassenso -, mas uma orientação para que atuem em harmonia e com lealdade recíproca em busca da prestação da tutela jurisdicional justa e efetiva. ${ }^{3} \mathrm{E}$ a cooperação, claro, é entre todos os sujeitos do processo: partes e juiz.

É nesse contexto que surge o art. 190 do NCPC, ao prever o chamado negócio jurídico processual:

Art. 190. Versando o processo sobre direitos que admitam autocomposição, é lícito às partes plenamente capazes estipular mudanças no procedimento para ajustá-lo às especificidades da causa e convencionar sobre os seus ônus, poderes, faculdades e deveres processuais, antes ou durante o processo.

Parágrafo único. De ofício ou a requerimento, o juiz controlará a validade das convenções previstas neste artigo, recusando-lhes aplicação somente nos casos de nulidade ou de inserção abusiva em contrato de adesão ou em que alguma parte se encontre em manifesta situação de vulnerabilidade.

O que se quer é valorizar o consenso nas questões processuais que tantas vezes se tornam as grandes vilãs da justiça, com ênfase na autonomia da vontade das partes, tudo de forma a propiciar o redimensionamento e a democratização do próprio papel do poder judiciário e do modelo de prestação jurisdicional pretendido; ${ }^{4}$ ou seja, é a atividade jurisdicional racionalizando e otimizando seus métodos em busca da efetividade e da eficácia do direito, privilegiando o princípio da primazia da resolução do mérito. ${ }^{5}$

técnica processual, em última análise, destina-se a assegurar o justo processo, ou seja, aquele desejado pelo legislador ao estabelecer o modelo constitucional ou devido processo constitucional. De nada adiante o processo regular do ponto de vista formal, mas substancialmente em desacordo com os valores constitucionais que o regem" (BEDAQUE, José Roberto dos Santos. Efetividade do processo e técnica processual. São Paulo: Malheiros, 2006. p. 26).

3 BUENO, Cassio Scarpinella. Novo Código de Processo Civil anotado. São Paulo: Saraiva, 2015.

4 CUNHA, Leonardo Carneiro da. Negócio jurídicos processuais no processo civil brasileiro. In: CABRAL, Antonio de passos; NOGUEIRA, Pedro Henrique (Coord.). Negócios processuais. Salvador: Juspodivm, 2015.

5 Refletida em diversos dispositivos do NCPC, de que são exemplos os art. 317, 321 e 801. 
Por se tratar de ato praticado no âmbito da autonomia da vontade das partes, sua aplicação está restrita aos direitos que admitam autocomposição. Nesse contexto, como efetivar a ideia de um processo consensual quando em um dos polos da lide está a Fazenda Pública? Isto é, quando o direito que se pretende tutelar está diretamente relacionado com o princípio da indisponibilidade do interesse público?

Especificamente na seara tributária, a atuação vinculada da administração (que, portanto, em princípio não teria flexibilidade ou autonomia para negociar) pode parecer vir refletida no art. $3^{\circ}$ do Código Tributário Nacional (CTN): "Tributo é toda prestação pecuniária compulsória, em moeda ou cujo valor nela se possa exprimir, que não constitua sanção de ato ilícito, instituída em lei e cobrada mediante atividade administrativa plenamente vinculada".

Não identificamos nenhum óbice à celebração de negócios jurídicos processuais entre Fazenda Pública e particular; ao contrário, no âmbito do Estado Democrático de Direito, em que não mais se admite que a administração atue de forma rígida e unilateral, deve ser estimulada a celebração de negócios jurídicos processuais, como forma também de propiciar o diálogo entre administração e administrado. Mas não só por isso, como se verá.

\section{LINHAS GERAIS SOBRE OS NEGÓCIOS JURÍDICOS PROCESSUAIS E SUA POSITIVAÇÃO NO NCPC}

A análise dos negócios jurídicos processuais deve ser precedida pelo exame do conceito de negócio jurídico. Segundo Miguel Reale, (acho que essa parte também deveria ficar em rodapé) $)^{6 .}$

negócio jurídico é aquela espécie de ato jurídico que, além de se originar de um ato de vontade, implica a declaração expressa da vontade, instauradora de uma relação entre dois ou mais sujeitos tendo em vista um objetivo protegido pelo ordenamento jurídico. Tais atos, que culminam numa relação intersubjetiva, não se confundem com os atos jurídicos em sentido estrito, nos quais não há acordo de vontade, como, por exemplo, se dá nos chamados atos materiais, como os da ocupação ou posse de um terreno, a edificação de uma casa no terreno apossado, etc.

6 REALE. Miguel. Lições preliminares de direito. 27. ed. São Paulo: Saraiva, 2004. p. 208-209. 
Amanifestação de vontade das partes é o núcleo central do instituto, o cerne da teoria dos negócios jurídicos. Vale dizer, a declaração de vontade de criar a relação jurídica é essencial para sua existência. Apesar de os negócios jurídicos terem se originado no âmbito do direito privado, no qual se desenvolveram com maior amplitude, há negócios jurídicos que nascem no decorrer da relação jurídica processual. ${ }^{7}$

A ideia de negócio processual, como bem aponta a doutrina, não representa propriamente uma novidade no sistema jurídico, que já contava com algumas modalidades típicas ao tempo do Código de Processo Civil de 1973 (CPC/73), como a possibilidade de modificação das regras de competência relativa (foro de eleição), a suspensão do processo por vontade das partes, o adiamento de audiência e a repartição do ônus da prova. ${ }^{8}$ A novidade é a instituição dessa cláusula geral, como verdadeiro incentivo à celebração do negócio processual, inclusive os atípicos, privilegiando a autonomia da vontade das partes e, substancialmente, visando eliminar os entraves processuais burocráticos que postergam a resolução do mérito.

O art. 190, cláusula geral dos negócios jurídicos processuais, ${ }^{9}$ possibilita que as partes, mediante manifestação de vontade, ${ }^{10}$ disponham sobre procedimento, ônus, faculdades e deveres processuais, com o objetivo de racionalizar, otimizar e colaborar com a prestação da tutela jurisdicional. ${ }^{11}$

7 Nas palavras de Pontes de Miranda: "Há negócios jurídicos que se perfazem durante relação jurídica processual. [...] Alguns negócios jurídicos privados são conteúdo de ato processual (a transação judicial, a compensação etc.). Vistos pelo lado do direito processual, são atos processuais. Vistos pelo lado do direito material, são negócios jurídicos privados. Os dois ramos do direito enlaçam o mesmo ato, submetendo-o aos seus preceitos. Os efeitos de direito material independem da eficácia ou subsistência da eficácia como ato processual, salvo regra do direito material" (PONTES DE MIRANDA, Francisco Cavalcanti. Tratado de direito privado. 4. ed. São Paulo: RT, 1983).

8 Respectivamente, art. 111, 265, inciso II, § $3^{\circ}, 453$, inciso I, e 333. Neste sentido, YARSHELL, Flavio Luiz. Convenção das partes em matéria processual: rumo a uma nova era? In: CABRAL, Antonio de Passos; NOGUEIRA, Pedro Henrique (Coord.). Negócios processuais. Salvador: Juspodivm, 2016. p. 75.

9 Os ilustres professores Nelson Nery Junior e Rosa Maria de Andrade Nery intitulam o referido dispositivo como uma verdadeira cláusula geral de atipicidade de negócios processuais. (NERY JUNIOR, Nelson; NERY, Rosa Maria de Andrade. Comentários ao Código de Processo Civil. São Paulo: Revista dos Tribunais, 2015).

10 Enunciado do Fórum Permanente de Processualistas Civis (FPPC) n. 404: "Nos negócios juridicos, atender-se-á mais à intenção consubstanciada na manifestação de vontade do que ao sentido literal da linguagem".

11 Enunciado FPPC n, 405: "Os negócios jurídicos processuais devem ser interpretados conforme a boa-fé e os usos do lugar de sua celebração". Enunciado FPPC n. 407: "Nos negócios processuais, 
Como bem sistematizado por Mirna Cianci e Bruno Lopes Megna, ${ }^{12}$ a regra geral dos negócios jurídicos processuais exige que sejam celebrados (i) somente por sujeitos processuais capazes (agentes); (ii) antes ou durante o curso do processo (tempo), (iii) em sede judicial (lugar), (iv) envolvendo direito que admita autocomposição (matéria) ${ }^{13}$ (v) podendo expressar declarações de vontade (forma) para (iv) estipular mudanças no procedimento de forma a ajustá-lo às especificidades da causa e convencionar sobre os seus ônus, poderes, faculdades e deveres processuais (objeto).

Em que pese a aparente abrangência da disposição, sua aplicação fica sujeita a controle de validade pelo juiz, de ofício ou a requerimento da parte. O juiz deverá recusar aplicação à convenção em casos de nulidade e de inserção abusiva em contrato de adesão ou em que alguma parte se encontre em manifesta situação de vulnerabilidade.

No campo da validade, por se tratar de negócio jurídico, aplicam-se, de regra e no que for pertinente, os mesmos princípios e condições que regem os negócios jurídicos em geral previstos no Código Civil $^{14}$ sem prejuízo, claro, das especificidades da legislação processual que devem ser observadas. A título de exemplo, convenção processual que admitisse a utilização de prova ilícita haveria de ser rechaçada, por ilegal (objeto ilícito). ${ }^{15}$

A doutrina tem cuidado de sistematizar o espaço não reservado à autocomposição processual: de modo geral, tudo aquilo que interfira no exercício do poder do Estado (jurisdição), no devido processo legal, na igualdade entre os litigantes (a chamada paridade de armas), nos poderes do juiz e em normas processuais cogentes. É bem verdade que a fórmula, assim colocada, não fica isenta de

as partes e o juiz são obrigados a guardar nas tratativas, na conclusão e na execução do negócio o princípio da boa-fé".

12 CIANCI, Mirna; MEGNA, Bruno Lopes. Fazenda Pública e negócios juridicos processuais no novo CPC: pontos de partida para o estudo. In: CABRAL, Antonio de Passos; NOGUEIRA, Pedro Henrique (Coord.). Negócios processuais. 2. ed. atual. e ampl. Salvador: Juspodivm, 2016. p. 623-624.

13 Enunciado FPPC n. 135: "A indisponibilidade do direito material não impede, por si só, a celebração de negócio jurídico processual".

14 Art. 104 e seguintes do Código Civil.

15 Enunciado da Escola Nacional de Formação e Aperfeiçoamento de Magistrados (Enfam) n. 37: "São nulas, por ilicitude do objeto, as convenções processuais que violem as garantias constitucionais do processo, tais como as que: a) autorizem o uso de prova ilicita; b) limitem a publicidade do processo para além das hipóteses expressamente previstas em lei; c) modifiquem o regime de competência absoluta; e d) dispensem o dever de motivação". 
dúvidas, pela generalidade, não havendo aqui também qualquer pretensão de esgotar o tema, que é ainda bastante recente.

Interferir na jurisdição e no devido processo legal (e, por conseguinte, em norma cogente) é, por exemplo, pretender limitar o exercício da atividade do juiz, as partes estipularem recurso não previsto em lei, dispensarem o dever de motivação das decisões judiciais, pretenderem modificar regras sobre competência absoluta, instituírem novas hipóteses de ação rescisória, dentre outros. ${ }^{16}$

Mas, por outro lado, nada impede que as partes convencionem reduzir os prazos processuais de comum acordo, ou concordem em não apresentar recursos de sentença ou acórdãos em segundo grau de jurisdição, a bem de uma prestação jurisdicional mais célere, ${ }^{17}$ justamente porque os prazos e os recursos são instituídos como direito e prerrogativa das partes, que podem dos primeiros se utilizar em tempo mais exíguo e dos segundos sequer se valerem, conformando-se com o resultado da decisão recorrível. Esse seria um negócio processual atípico plenamente cabível.

Portanto, respeitados os limites mencionados, voltados à ordem pública, ao controle de validade e à eventual hipossuficiência de uma das partes que possa resultar em desigualdade no plano processual, nada impede que as partes, em comum acordo, estabeleçam outros negócios jurídicos processuais (atípicos), ${ }^{18}$ visando à efetividade do direito pelo e no processo. O propósito do instituto é prestigiar a autorregulação consensual das partes no que diz respeito às suas próprias posições, ônus e faculdades, sem que exista a prolação de uma decisão

16 Neste sentido, o Enunciado Enfam n. 36: "A regra do art. 190 do CPC/2015 não autoriza às partes a celebração de negócios jurídicos processuais atípicos que afetem poderes e deveres do juiz, tais como os que: a) limitem seus poderes de instrução ou de sanção à litigância improba; b) subtraiam do Estado/juiz o controle da legitimidade das partes ou do ingresso de amicus curiae; $c$ ) introduzam novas hipóteses de recorribilidade, de rescisória ou de sustentação oral não previstas em lei; d) estipulem o julgamento do conflito com base em lei diversa da nacional vigente; e e) estabeleçam prioridade de julgamento não prevista em lei".

17 Se este tipo de estipulação (supressão de recurso em processo envolvendo a Fazenda Pública) é cabivel é matéria objeto do tópico seguinte.

18 A título exemplificativo, são passíveis de negócio jurídico, dentre outros: renúncia ao direito de interpor recurso, convenção sobre a distribuição do ônus da prova, eleição do foro em que deve ser processada e julgada a ação e acordo de penhorabilidade ou impenhorabilidade. Igualmente, o FPPC editou o Enunciado n. 490, que apresenta um rol exemplificativo de negócios jurídicos processuais admissiveis. 
judicial de acertamento de direitos,$^{19}$ ou seja, efetivada pela simples negociação direta, sujeita a controle jurisdicional.

Dessa forma, o magistrado deixa de atuar somente como aplicador do direito para também operar como agente de controle dos negócios processuais, de forma a se aproximar de seus interlocutores. Nesse sentido:

O juiz passa a ter um novo perfil funcional: não é mais autoridade que se presta unicamente a dizer o direito: é autoridade que - com atuação conciliadora - se volta para recepcionar as partes, em seus lídimos anseios, para que elas possam ajudá-lo a dizer o direito, conformado para a experiência de cada um dos litigantes. Doravante as partes - no processo civil em geral - assumem um papel de interlocução mais próxima do juiz, não como antagonistas que aguardam decisão, mais como protagonistas que constroem a decisão. $\mathrm{O}$ juiz, de sua parte, deixa de exercer a autoridade como uma dádiva ao súdito, mas permite que as partes o ajudem na tarefa de escolher a solução e dá-la na dose devida aos pacientes. ${ }^{20}$

\section{NEGÓCIOS JURÍDICOS PROCESSUAIS E SUA APLICABILIDADE NAS LIDES TRIBUTÁRIAS}

A questão fundamental que surge nos processos envolvendo Fazenda Pública e contribuinte é se, diante da indisponibilidade do interesse público, e tratando-se a atividade administrativa de arrecadar tributos plenamente vinculada (art. $3^{\circ}$, CTN), como referido no preâmbulo deste texto, haveria espaço para celebração de negócio jurídico processual, que só é possível quando versem sobre direitos que admitam autocomposição.

Fixemos desde logo nossa premissa. Parece-nos que os direitos a que se refere a norma do art. 190 do NCPC não são os direitos materiais controvertidos em juízo, cujo mérito da causa será solucionado pelo juiz. O negócio processual se destina a fazer, de comum acordo, modificações no procedimento para ajustá-lo

19 WAMBIER, Tereza Arruda Alvim. Primeiros comentários ao Novo Código de Processo Civil: artigo por artigo. São Paulo: Revista dos Tribunais, 2015.

20 NERY JUNIOR, Nelson; NERY, Rosa Maria de Andrade. Comentários ao Código de Processo Civil. São Paulo: Revista dos Tribunais, 2015. p. 760. 
às especificidades da causa na atribuição de ônus da prova, na convenção sobre poderes, ônus e deveres processuais. Ou seja: direitos tipicamente processuais.

Portanto, os direitos que admitam autocomposição, a nosso ver, só podem ser os direitos processuais que serão objeto dos negócios jurídicos de que trata o art. $190 .{ }^{21}$ Estarão fora desse espectro, como visto, as normas cogentes referidas na seção precedente $\mathrm{e}^{22}$ e todas as demais que de alguma forma possam violar a paridade de armas, o devido processo legal ou limitar os poderes do juiz; além, é claro, daquelas taxativamente expressas no próprio art. 190.

Ainda para quem não compartilhe desse entendimento e veja na norma do art. 190 do NCPC a expressão "direitos que admitam autocomposição" como envolvendo a própria pretensão de direito material deduzida em juízo, tampouco nos parece haver empecilhos à celebração de negócio jurídico processual entre Fazenda Pública e contribuinte. A indisponibilidade do interesse público, aqui, precisa ser desmistificada.

A autocomposição em casos em que a Fazenda Pública atua como parte sempre foi objeto de discussão à luz da antiga dicotomia público vs. privado, tradicionalmente colocado como empecilho à transação o mito da supremacia do interesse público. Pensamos que o cerne da discussão está nos limites da indisponibilidade dos direitos da administração. Sob um prisma mais conservador, diz-se que, por se tratar de interesse público, não é passível de autocomposição (transição, renúncia ou submissão). Doutra parte, adotando-se visão voltada à cooperação entre administração e administrado - que reflete a postura contemporânea do Estado e do direito administrativo -, entendemos ser perfeitamente possível admitir a autocomposição nessa seara, sem ferir o interesse público stricto sensu. ${ }^{23}$

21 Neste sentido parece ser o entendimento de YARSHELL, Flavio Luiz. Convenção das partes em matéria processual: rumo a uma nova era? In: CABRAL, Antonio de Passos; NOGUEIRA, Pedro Henrique (Coord.). Negócios processuais. Salvador: Juspodivm, 2016. Ainda a esse respeito, MENDONÇA NETO, Delosmar Domingues de. Negócio jurídico processual, direitos que admitem a autocomposição e o pactum de non petendo. Revista de Processo, v. 272, p. 419-439, out. 2017.

22 Flavio Luiz Yarshell destaca a dificuldade de se estabelecer um parâmetro taxativo do que seriam essas normas. YARSHELL, Flavio Luiz. Convenção das partes em matéria processual: rumo a uma nova era? In: CABRAL, Antonio de Passos; NOGUEIRA, Pedro Henrique (Coord.). Negócios processuais. Salvador: Juspodivm, 2016.

ÁVILA, Humberto. Repensando o "Principio da Supremacia do Interesse Público sobre o Particular". In: SARMENTO, Daniel (Org.). Interesses públicos versus Interesses privados: desconstruindo o principio da supremacia do interesse público. Rio de Janeiro: Lumen Juris, 2010. 
Como já destacamos em outra oportunidade, referindo à obra de Bandeira de Mello, é mito supor que interesse público e particular sejam antagônicos. Se é verdade que o interesse do particular, baseado em suas conveniências pessoais, pode eventualmente se contrapor ao interesse público, não é menos verdadeiro que interesse público é a "dimensão pública dos interesses individuais, ou seja, de cada indivíduo enquanto partícipe da sociedade". ${ }^{24}$ Portanto, interesse público (primário) não se confunde com interesse da Fazenda Pública (secundário). ${ }^{25}$

A visão contemporânea do Estado, em que a administração tem limites muito rigorosos de atuação, pautados que são pelos mandamentos contidos no art. 37 da Constituição Federal de 1988, não admite mais enxergá-lo como agente superior, tanto mais no âmbito do processo, em que atua como parte e se coloca em situação de absoluta igualdade perante o particular, a ser fiscalizada e garantida pelo Estado-juiz. A interpretação razoável e, principalmente, atual da essência conceitual de Estado e de interesse público não está engessada nas visões originárias de sua concepção, tendo em vista que a administração não deve mais atuar sob a perspectiva imperativa e monológica que bloqueia os mecanismos comunicacionais com seus administrados, ${ }^{26}$ o que leva a uma releitura de sua função tradicional.

Portanto, em tempos atuais, o Estado deve ser visto como (i) democrático, no sentido de transmitir seus valores, interesses e necessidades com respaldo de toda a sociedade, que tem o direito de exercer o acompanhamento e controle de seus atos; (ii) dialógico, possibilitando o melhor debate com os administrados; (iii) argumentativo, mantendo a coerência, a lógica e a integridade de suas ações perante todos; (iv) consensual, vislumbrando uma maior eficiência de suas decisões e maximizando os benefícios; e (v) motivado, no sentido de justificar suas ações em linha com a argumentação traçada. ${ }^{27}$

24 BANDEIRA DE MELLO, Celso Antonio. Grandes temas atuais de direito administrativo. São Paulo: Malheiros, 2009. p. 182.

25 ZAGARI, Daniella; VIEIRA, Maria Eugenia Doin; PEIXOTO, Daniel Monteiro. In: Garantias judiciais no processo tributário: cenários, perspectivas e desafios. São Paulo: Blucher, 2018.

26 OLIVEIRA, Gustavo Justino de. Direito Administrativo Democrático. Belo Horizonte: Fórum, 2010.

27 NETO, Diogo de Figueiredo Moreira. O Futuro do Direito Administrativo no policentrismo de suas fontes. O Direito Administrativo global e os rumos do ordenamento jurídico pós-moderno. In: BANDEIRA DE MELLO, Celso Antônio; FERRAZ, Sérgio; ROCHA, Silvio Luis Ferreira da; SAAD, Amauri Feres (Coord.). Direito Administrativo e Liberdade: estudos em homenagem a Lúcia Valle. São Paulo: Malheiros, 2014. p. 310-358. 
Nesse sentido, estamos com Priscila Faricelli de Mendonça, ${ }^{28}$ que, após percuciente análise doutrinária a respeito do tema, conclui que: "O que é indisponível é o dever do Estado de agir no interesse da sociedade e de acordo com os princípios constitucionais vigentes". E arremata:

Em verdade, o Estado deverá avaliar qual o interesse efetivamente envolvido na controvérsia e decidir pela solução que melhor atenda ao bem estar da coletividade. Desse modo, uma solução de determinada controvérsia não deverá ser avaliada mediante análise exclusiva da relação em jogo, mas sim dos objetivos institucionais do Estado e da demanda social.

E, ainda nesse sentido, não é a indisponibilidade do direito em si que lhe retira a faculdade de autocomposição. Como bem demonstram Mirna Cianci e Bruno Lopes Megna ${ }^{29}$ a experiência jurídica é pródiga na utilização de meios consensuais e alternativos para resolução de controvérsias no âmbito dos chamados direitos indisponíveis (acordos no âmbito criminal envolvendo casos de menor potencial ofensivo nos juizados especiais, acordos em contratos administrativos, possibilidade de transação em juizados especiais, indenizações administrativas por danos causados por agente público).

Em âmbito tributário não se dá de forma diferente, e a questão tampouco oferece maiores desafios, tanto que se encontra largamente sedimentada em nossa experiência cotidiana a oportunidade de se transacionar com o Fisco, o que conta com previsão legal expressa no art. 171 do $\mathrm{CTN}^{30}$ sendo causa de extinção do crédito tributário (art. 156, inciso III, do mesmo diploma). ${ }^{31}$ Os inúmeros programas de parcelamento de dívidas, redução de multa e juros para término de litígios tributários em todas as esferas - municipais, estaduais e federal - bem o demonstram, e não deixam de refletir modalidade de autocomposição, pois a Fazenda renuncia

28 MENDONÇA. Priscila Faricelli de. Arbitragem e transação tributárias. Brasília: Gazeta Jurídica, 2014. p. 35-36.

29 Conferir com maiores detalhes CIANCI, Mirna; MEGNA, Bruno Lopes. Fazenda Pública e negócios jurídicos processuais no novo CPC: pontos de partida para o estudo. In: CABRAL, Antonio de Passos; NOGUEIRA, Pedro Henrique (Coord.). Negócios processuais. 2. ed. atual. e ampl. Salvador: Juspodivm, 2016. p. 628-629.

30 "Art. 171. A lei pode facultar, nas condições que estabeleça, aos sujeitos ativo e passivo da obrigação tributária celebrar transação que, mediante concessões mútuas, importe em terminação do litígio e consequente extinção do crédito tributário."

31 "Art. 156. Extinguem o crédito tributário: [...] III - a transação." 
à parte do crédito a que entendia fazer jus, e o contribuinte renuncia à discussão administrativa ou judicial na qual poderia vir a se sagrar vencedor. Típica hipótese de acordo de concessões mútuas, que é a definição por excelência do mecanismo de transação.

E aqui vale retomar o conceito de tributo e a atividade de sua cobrança, vinculada, tal qual disposto no art. $3^{\circ}$ do CTN. Como destacado por Priscila Faricelli de Mendonça, ${ }^{32}$ o tributo é prestação pecuniária e, portanto, envolve um direito patrimonial, em essência disponível. Contudo, sua exigência envolve uma atividade estatal vinculada, indisponível. Essa aparente dicotomia não é de difícil solução. A mesma autora bem esclarece que o texto do art. $3^{\circ}$ distingue o crédito tributário (moeda, disponível) da atividade atribuída à administração de constituí-lo, cobrá-lo e arrecadá-lo, essa sim indisponível, vinculada e não sujeita a transação, adstrita que está aos limites intransponíveis do art. 37 da Constituição Federal.

E a disponibilidade sobre o crédito em si, claro, não significa discricionariedade da administração. Deve atender também a todos os princípios antes referidos: perseguição do verdadeiro interesse público (primário), colaboração com o administrado, identificação, no caso concreto, do bem comum e a ser preservado e ponderação dos interesses em jogo. Sempre sob a ótica da legalidade. "Não se pode, portanto, de forma alguma confundir indisponibilidade com intransigibilidade, pois esta somente se afigura nas situações em que a lei expressamente veda a transação". 33

Assim, concluímos esta seção com a convicção de que não há nenhum óbice à celebração de negócio jurídico processual entre Fazenda Pública e contribuinte em processos tributários. ${ }^{34}$ Resta averiguar, e sem nenhuma pretensão de exaurir o tema, se há limites a essa celebração, além daqueles já apontados e que envolvem os litigantes de modo geral.

32 MENDONÇA. Priscila Faricelli de. Arbitragem e transação tributárias. Brasilia, DF: Gazeta Jurídica, 2014.

33 SOUZA, Luciane Moessa de. Resolução consensual de conflitos envolvendo o Poder Público: caminho possivel e adequado, com o devido respeito às peculiaridades do regime jurídico-administrativo. Revista do Advogado, São Paulo, v. 34, p. 162-169, ago. 2014.

34 Enunciado FPPC n. 256: "A Fazenda Pública pode celebrar negócio jurídico processual". Enunciado do Conselho da Justiça Federal (CJF) n. 17: "A Fazenda Pública pode celebrar convenção processual, nos termos do art. 190 do CPC". 


\section{NEGÓCIOS JURÍDICOS PROCESSUAIS EM ESPÉCIE E A FAZENDA PÚBLICA}

Não poderíamos iniciar esta seção sem fazer referência à iniciativa pioneira da Procuradoria-Geral da Fazenda Nacional (PGFN) em torno do tema. Merece destaque, nesse contexto, a Portaria PGFN n. 33, de 8 de fevereiro de $2018,{ }^{35}$ que passou a prever expressamente, em seu art. $38,{ }^{36}$ a possibilidade de o procurador celebrar com o contribuinte negócio jurídico processual, visando à recuperação dos débitos em tempo razoável ou obtenção de garantias em dinheiro.

No mesmo sentido, destacamos a possibilidade de oferta antecipada de bens em garantia, com maior flexibilidade no oferecimento e sem distinção entre depósito, carta-fiança, seguro garantia ou bens suscetíveis de registro (art. $9^{\circ}$ e seguintes). Trata-se de negócio jurídico processual atípico a ser celebrado na fase pré-processual, com o escopo de desafogar o judiciário e simplificar o procedimento, permitindo que, quando do ajuizamento da execução fiscal, o mérito possa ser encaminhado para julgamento, via embargos à execução, de forma mais célere.

Aqui, a única crítica (construtiva) que se faz, visando ao aperfeiçoamento do instituto, é a necessidade de melhor se regulamentar a denominada fase do limbo, entre a constituição definitiva do crédito tributário e a inscrição em dívida ativa, na qual o contribuinte idôneo não pode ficar privado da certidão de regularidade fiscal. Sem que essa questão seja devidamente endereçada, esse novel instituto, muito bem engendrado, poderá ficar sensivelmente esvaziado, obrigando que os contribuintes batam às portas do judiciário. É essencial, pois, que essa medida acautelatória seja considerada.

Posteriormente, a Portaria PGFN n. 360, de 13 de junho de 2018 (com alterações da Portaria PGFN n. 515, de 20 de agosto de 2018), trouxe algumas outras

35 Por não ser o foco deste estudo, deixamos de dar destaque a outros pontos da Portaria que, a nosso ver, são merecedores de inúmeras críticas, especialmente aqueles voltados à regulamentação da inconstitucional Lei n. 10.522, de 19 de julho de 2002, no que concerne à malfada "penhora administrativa".

36 "Art. 38. O Procurador da Fazenda Nacional poderá celebrar Negócio Jurídico Processual visando a recuperação dos débitos em tempo razoável ou obtenção de garantias em dinheiro, isoladamente ou em conjunto com bens idôneos a serem substituídos em prazo determinado, inclusive mediante penhora de faturamento, observado o procedimento disposto no regulamento expedido pela Procuradoria-Geral da Fazenda Nacional." 
hipóteses em que a PGFN está autorizada a celebrar negócio jurídico processual. ${ }^{37}$ Dentre essas hipóteses destacam-se, dentre outras, a calendarização processual (negócio processual típico, previsto no at. 191 do NCPC), estipulação de prazos processuais, ordem de realização de prazos processuais, cumprimento de decisões judiciais e confecção ou conferência de cálculos.

Tomando como referência a sistematização já proposta pela PGFN, comecemos pelo tema das garantias. É de se louvar a iniciativa (com as pequenas ressalvas já feitas), especialmente quando se pensa em um novo patamar na relação entre administração e administrado. É verdade que, em um segundo momento, essa relação, que ainda está na fase pré-processual, será submetida ao crivo do Estado-juiz, a quem caberá velar pela estrita igualdade das partes. Mas na fase pré-processual (ou mesmo na fase processual), a quem interessa uma interminável discussão sobre garantias, que muitas vezes se arrasta por anos e anos, prejudicando o desfecho da causa? Prejudica o poder público, se ele tiver razão, e prejudica o particular, se ao lado dele estiver o direito. E isso quem dirá será o poder judiciário. É o que já se afirmava no preâmbulo: as questões processuais se tornam as grandes vilãs da justiça, e é preciso que haja bom-senso. Bom-senso em prol do verdadeiro interesse público, que não se confunde com o interesse da Fazenda Pública. Interesse público é tornar devido o tributo que realmente o seja, e exonerar o tributo indevido.

O exame criterioso da matéria tributária em discussão muitas vezes revela sua complexidade: não se pode saber de antemão quem tem razão. A intransigência

37 "Art. $1^{\circ}$. Sem prejuizo do disposto no art. 12 da Portaria PGFN N 502, de 12 maio de 2016, e nos arts. $9^{\circ}$ e 10 da Portaria PGFN n 985 , de 18 de outubro de 2016, e noutros atos normativos da PGFN, fica a autorizada a celebração, no âmbito da Procuradoria-Geral da Fazenda Nacional, desde que observados os requisitos previstos no Código de Processo Civil, das seguintes modalidades específicas de negócio jurídico processual - NJP's, inclusive mediante a fixação de calendário para a prática de atos processuais: I - cumprimento de decisões judiciais; II - confecção ou conferência de cálculos; III - recursos, inclusive a sua desistência; IV - forma de inclusão do crédito fiscal e FGTS em quadro geral de credores, quando for o caso; $\mathrm{V}$ - prazos processuais; e VI - ordem de realização dos atos processuais, inclusive em relação à produção de provas. Parágrafo único. É vedada a celebração de negócio jurídico processual: I - cujo cumprimento dependa de outro órgão, sem que se demonstre a sua anuência prévia, expressa e inequívoca; II - que preveja penalidade pecuniária; III - que envolva qualquer disposição de direito material por parte da União, ressalvadas as hipóteses previstas Portaria PGFN № 502, de 12 maio de 2016, e na Portaria PGFN No 985, de 18 de outubro de 2016; IV - que extrapole os limites dos arts. 190 e 191 do Código de Processo Civil; ou V - que gere custos adicionais à União, exceto se aprovado prévia e expressamente pela Procuradoria-Geral Adjunta competente." 
em exigir, por exemplo, garantias em dinheiro, fianças bancárias ou seguros garantias (tantas vezes impossíveis de serem suportados) é muitas vezes um desserviço à economia, ao desenvolvimento do setor produtivo. $\mathrm{E}$ aos cofres do próprio poder público, não só pela descapitalização do contribuinte, mas porque, se ao fim e ao cabo o contribuinte sagra-se vencedor, todos esses custos terão de ser suportados pelo erário em ressarcimento. Ou seja, por todos nós.

É claro que essa é uma das faces da moeda. Há contribuintes manifestamente inidôneos e com histórico nesse sentido. Como há contribuintes que querem, mas não podem garantir o débito em sua integralidade. Não sem desconstituir a própria fonte produtora de riqueza que gerará o pagamento de tributos e permitirá sua retomada. Mas é disso que se trata: separar o joio do trigo. Aproximar a administração do administrado para que ela sopese verdadeiramente os interesses em jogo em espírito colaborativo, a bem do interesse público.

A calendarização processual prevista no art. 191 do NCPC, ${ }^{38}$ negócio processual típico e que reflete este novo modelo gerencial de processo pretendido pelo legislador, é uma inovação e tanto. Se bem incorporada à mentalidade dos operadores do direito, especialmente no âmbito da Fazenda Pública, é apta a conduzir a resultados excepcionais em termos de efetividade e previsibilidade na prestação jurisdicional.

Em linhas gerais, a calendarização processual nada mais é que a convenção acerca dos prazos dos atos a serem praticados no decorrer do processo pelos seus sujeitos do processo. No processo tributário, se bem utilizado, o instituto representará a potencialização da máquina judiciária como instrumento de solução de conflitos, de forma a superar, ao menos em tese, a morosidade inerente ao próprio sistema judiciário. Isso porque as partes e o juiz estarão vinculados às datas convencionadas de comum acordo, possibilitando que se preveja com segurança o início e o término do processo, minando a insegurança jurídica de uma lide que pode perdurar por anos.

Como em qualquer processo judicial, o calendário estabelecido na lide tributária não poderá ignorar a previsão contida no art. 12, caput, do NCPC, ${ }^{39}$ que de certa

38 "Art. 191. De comum acordo, o juiz e as partes podem fixar calendário para a prática dos atos processuais, quando for o caso. $\S 1^{\circ} \mathrm{O}$ calendário vincula as partes e o juiz, e os prazos nele previstos somente serão modificados em casos excepcionais, devidamente justificados. $\S 2^{\circ}$ Dispensa-se a intimação das partes para a prática de ato processual ou a realização de audiência cujas datas tiverem sido designadas no calendário."

39 "Art. 12. Os juízes e os tribunais atenderão, preferencialmente, à ordem cronológica de conclusão para proferir sentença ou acórdão." 
forma vincula o magistrado a uma ordem cronológica de julgamento. Respeitada essa ordem, não há razão para afastar a celebração desse tipo de negócio jurídico em processos que discutam relações jurídico-tributárias.

Outro exemplo que traduziria o espírito do instituto dentro do processo tributário é a realização antecipada de provas, nos termos do art. 381, inciso II, do NCPC. ${ }^{40}$ Recorde-se que esse dispositivo é uma novidade do NCPC: a produção da prova é realizada de modo a viabilizar a composição entre as partes.

Considere-se uma autuação fiscal que verse sobre questão que dependa, necessária e exclusivamente, da análise de documentos fiscais e contábeis do contribuinte, mediante prova pericial. Uma vez encerrado o processo na esfera contenciosa administrativa com a manutenção do crédito tributário (tendo havido o contraditório ou não), o débito será automaticamente encaminhado para cobrança e inscrição em dívida ativa do ente tributante, sendo o título extrajudicial passível de execução a qualquer tempo.

Pela complexidade da questão técnica envolvida, não se sabe, de antemão, quem obterá êxito na demanda. Fazenda Pública e contribuinte estão em situação de risco, podem ou não se sagrarem vencedores em eventual demanda que tramitará por anos a fio. Assim, a produção antecipada da prova pericial, sendo esta a única questão controvertida que definirá a existência ou não do crédito tributário, pode evitar uma demanda tributária na qual o contribuinte ou a Fazenda sairiam sucumbentes (com todos os respectivos ônus daí decorrentes). A confecção ou conferência de cálculos de que trata a Portaria PGFN n. 360/2018 em muito se aproxima dessa ideia.

Ainda sobre a produção antecipada de provas como negócio processual destinado a prevenir litígios, as partes poderiam pleitear em juízo, de comum acordo, a concessão de tutela de urgência para suspensão de exigibilidade do crédito tributário no curso do procedimento, como medida acautelatória e para que o próprio escopo visado não fosse esvaziado. Embora esse tipo de procedimento não se sujeite a uma decisão de mérito pelo juiz (o que não faria sentido), ele está sujeito a controle de legalidade e validade no âmbito jurisdicional, o que lhe confere as mais amplas legitimidade e credibilidade.

40 "Art. 381. A produção antecipada da prova será admitida nos casos em que: I - haja fundado receio de que venha a tornar-se impossivel ou muito difícil a verificação de certos fatos na pendência da ação; II - a prova a ser produzida seja suscetivel de viabilizar a autocomposição ou outro meio adequado de solução de conflito; III - o prévio conhecimento dos fatos possa justificar ou evitar o ajuizamento de ação." 
Não impressiona, por outro lado, argumento no sentido de que eventual resultado favorável da perícia ao contribuinte não poderia conduzir à extinção do crédito tributário, diante das hipóteses taxativas do art. 156 do CTN. Lembre-se, a esse respeito, de que compete à procuradoria do respectivo entre público o controle de legalidade da inscrição da dívida ativa, e que esta goza de presunção apenas relativa de certeza, liquidez e exigibilidade, que certamente estaria comprometida com esse resultado (art. $2^{\circ}$, $\ 3^{\circ}$, e $3^{\circ}$, $\$ único, da Lei n. 6.830/1980).

De outro lado, o contribuinte assumiria o compromisso de liquidar o crédito tributário em caso de resultado desfavorável na prova produzida, confessando a respectiva dívida. Nessa sistemática, as partes não utilizariam as provas como instrumento de convencimento do magistrado, mas essencialmente como método de auxílio na valorização de suas chances de êxito na demanda, contribuindo, assim, para que o processo alcance o resultado que dele se espera, ${ }^{41}$ com a solução efetiva da controvérsia em razoável período de tempo.

Esses são apenas pequenos exemplos de infindáveis possibilidades que a casuística e a experiência forense poderão nos trazer. Há, é claro, algumas questões polêmicas. Embora seja possível dizer assente o entendimento de que as partes podem, por vontade própria, renunciar a recursos que estariam à sua disposição, há quem não admita que esse direito seja exercido pela Fazenda Pública no que diz respeito à remessa oficial, fora as hipóteses de dispensa legal, por se tratar de norma cogente (como aquelas que dispensassem a intervenção do Ministério Público em processos de participação obrigatória) ${ }^{42}$

Outro ponto polêmico se refere ao princípio da isonomia. Segundo Mirna Cianci e Bruno Lopes Megna, ${ }^{43}$ este seria o aspecto mais relevante: "A toda evidência, a possibilidade de realizar negócio jurídico processual com um administrado deve ser estendida para todos os demais administrados, o que certamente há de ser assegurado mediante regulamentações próprias de cada entre da federação, como, de fato, muitos já fazem".

41 WAMBIER, Tereza Arruda Alvim. Primeiros comentários ao Novo Código de Processo Civil: artigo por artigo. São Paulo: Revista dos Tribunais, 2015.

42 Neste sentido, CUNHA, Leonardo Carneiro da. Negócio jurídicos processuais no processo civil brasileiro. In: CABRAL, Antonio de Passos; NOGUEIRA, Pedro Henrique (Coord.). Negócios processuais. Salvador: Juspodivm, 2015.

43 CIANCI, Mirna; MEGNA, Bruno Lopes. Fazenda Pública e negócios juridicos processuais no novo CPC: pontos de partida para o estudo. In: CABRAL, Antonio de Passos; NOGUEIRA, Pedro Henrique (Coord.). Negócios processuais. 2. ed. atual. e ampl. Salvador: Juspodivm, 2016. p. 633 
Não há dúvida de que a regulamentação, no âmbito da Fazenda Pública, é de todo recomendável, até para que o instituto, que veio para facilitar e simplificar o procedimento, não se torne fonte de novos transtornos (definir se é cabível o negócio jurídico processual e se a Fazenda pode ou não celebrá-lo, à míngua de regulamentação específica do respectivo órgão). Pensamos, todavia, que o assunto merece de fato reflexão e que a celebração de negócio jurídico processual entre Fazenda Pública e contribuinte não está sujeita, como condição sine qua, por todas as razões expostas ao longo deste texto, à prévia regulamentação pelo órgão público a que pertença. Tanto mais quando celebrados no curso do processo e sujeitos a controle judicial.

A atenção às peculiaridades da causa é de suma importância. A perseguição do interesse público (mais uma vez, distinto do interesse da Fazenda Pública), o bom-senso, o princípio da cooperação, a maior aproximação entre administração e administrado em prol do bem comum, a busca pela efetividade do processo, todos esses valores não só podem como devem ser perseguidos pelo advogado público, tanto quanto pelo advogado privado.

Tomemos justamente o exemplo da isonomia. São inúmeros os casos de processos que permanecem por períodos extremamente longos em poder da PGFN, atrasando injustificadamente seu andamento regular. Outros não. Estamos aqui em uma clara situação de tratamento anti-isonômico, mas para a qual, aparentemente, não se lhe confere tal pecha. Em contrapartida, não vemos absolutamente nenhum obstáculo a que o advogado público, juntamente com o advogado privado e com a participação do juiz, decida que naquele dado processo, pelas peculiaridades da causa e para seu melhor gerenciamento, serão calendarizados os atos processuais. O mesmo se diga da negociação de garantias, dentre tantos outros exemplos que poderiam ser dados.

\section{CONSIDERAÇÕES FINAIS}

A cooperação entre as partes no processo judicial foi o mecanismo utilizado pelo legislador para incentivar alternativas consensuais que permitam a mais efetiva solução de litígios. Não bastasse o intuito de fomentar o bom andamento do processo, as partes agora assumem papel ainda mais importante para que o mérito possa ser julgado sem interferências desnecessárias e opressivas.

Pensamos que a melhor interpretação é aquela que vê como insuscetíveis de autocomposição não os direitos materiais sobre os quais se controverte, mas o direito processual, que pode sofrer algumas limitações no âmbito da autonomia 
da vontade das partes. Por isso, não identificamos nenhum óbice à celebração de negócios processuais entre Fazenda Pública e contribuinte. Mas, também para aqueles que relacionam o direito à celebração de negócio jurídico processual à possibilidade de autocomposição no plano do direito material controvertido, nossa conclusão é a mesma.

Mesmo que em um dos polos esteja a Fazenda Pública, a indisponibilidade de seus direitos já não é vista como algo absoluto, e hoje a aproximação entre administração e administrado é o que verdadeiramente deve caracterizar o interesse público, atuando todos em prol do bem comum. Deve-se prestigiar a participação democrática dos cidadãos nas decisões emanadas pela administração, em atitude colaborativa e participativa.

E direitos indisponíveis, de toda forma, admitem muitas vezes transação, tanto mais na sua vertente pecuniária, como é o caso do crédito tributário. Indisponíveis são as atividades de fiscalizar, lançar e arrecadar o tributo, mas não a sua expressão pecuniária. É claro o CTN neste sentido.

São admitidos - mais que isso, devem ser incentivados - os negócios jurídicos processuais entre Fazenda Pública e contribuinte. Nesse contexto, a PGFN tem se mostrado pioneira em sua regulamentação. A regulamentação não parece indispensável, mas é extremamente útil.

Cabe agora à comunidade jurídica debater essas questões de forma construtiva para que o instituto possa atingir seus maiores objetivos, gerando eficiência e efetividade na prestação jurisdicional e melhoria substancial na gestão de processos. Processo é meio, e não fim em si mesmo. 